\title{
Glass Fiber reinforced Compressed Stabilized Earth Block - A green alternative to Cement Concrete Blocks
}

\author{
Bright Brabin Winsley J, Muthukannan M
}

\begin{abstract}
Construction activity utilizes lot of resources and energy to manufacture and install building components. Most of the construction materials are cement based or poly ethylene products, which needs lot of embodied energy to produce and create problems related to environment. Reusing these products after its service life is also very difficult. Manufacturing of cement liberates almost equal amount of carbon di oxide by weight, all contribute towards global warming and depletion of natural resources. Use of mud and naturally available materials in buildings is evident in olden buildings found to be a sustainable alternative solution. Most of the historic buildings and monuments existing today were made with earth adobe and lime. The use of modern technology made the earth compressed at higher pressure to form as hard material, use of stabilizers like cement and lime made them stronger, durable and less water absorbent. Adding glass fibers in the mixture will improve the strength and crack resistance of the block. The objective of this study is to add glass fibers in the mixture to increase the strength and crack resistance of CSEB.
\end{abstract}

Keywords: compressive strength, water absorption, flexural strength, compressed earth block, sustainability

\section{INTRODUCTION}

B ricks are play an important role in all buildings for constructing load bearing walls and partition walls, provides insulation against heat and cold and transfers load. They are in the form of burned bricks, unburned bricks, solid concrete blocks, hollow concrete blocks, aerocon blocks. Manufacture of each type of brick utilize large amount of energy and valuable resources. The utilization of local available soil at site can be used in manufacturing Compressed Stabilized Earth Block (CSEB) at site. CSEB is a green alternative material to traditional bricks or concrete blocks. Utilizing the material at or nearby site reduces the cost of transportation and thus production. This allows faster production at much lesser cost. CSEB is an ecofriendly green product with negligible energy usage, zero pollution and $100 \%$ recyclable.

Revised Manuscript Received on December 5, 2019

* Correspondence Author

Bright Brabin Winsley $\mathbf{J}^{*}$, Department of Civil Engineering, Mar Ephraem College of Engineering and Technology, Elavuvillai, India. Email: brightwinsley@gmail.com

Muthukannan M, Department of Civil Engineering, Kalasalingam Academy of Research and Education, Virudhunagar, India. Email: civilkannan@gmail.com
Due to plenty of advantages with CSEB compared to other materials, it can be a promising building material. It reduces the cost of transportation because of utilizing locally available materials in situ and also plays a role on reducing materials importing for production and also give low cost good quality houses for poverty peoples. The Embodied energy of production phase it creates extremely low amount of waste and easily disposable too which couldn't cause no direct environmental pollution during the whole life cycle[4]. Due to the capacity of absorbing moistures available in atmosphere, CSEB was a predominant one to create eco- friendly and healthy environmental surrounding to the occupants. Buildings made with Earth blocks showed lesser indoor temperature when compared with conventional clay bricks [3]. Addition of cement as stabilizer increases the thermal conductivity and specific heat [7]. The major drawback of using earth alone as a building material was service life of construction which is strongly related to its compressive strength. Because of strength lack, instability and modification required for durability in most of the soils which was used as manufacturing of building materials. Addition of cement content as stabilizer improves the compressive strength in both dry and wet state, behavior of CSEB is similar to other masonry units in compressive strength[3] [6]. CSEB is produced by selecting suitable soil, preparing the soil by sieving, addition of stabilizers, moulding, compacting the mixture, stacking and curing. The strength and quality of CSEB purely depends upon the nature of the soil and the dosage of the stabilizers. CSEB when reinforced with glass fibers could show higher strength and crack resistance [7]. The primary objective of this study is to compare the compressive strength, flexural strength and moisture absorption of the CSEB with glass fiber reinforced CSEB.

Classification of bricks can be done on several ways such as ASTM C 62 Standard brick, ASTM C 216 Facing Brick, ASTM C 652 Hollow brick and ASTM C 1088 Thin veneer brick. For the purpose of insulation, ASTM C 62 brick was used in non-load bearing and load bearing structures. The categorization of brick was made by following: Fired brick, unfired brick, Brick made up of clay and mortar. From the process of production, normal brick was differed from CSEB brick. CSEB brick needs static, dynamic or vibrostatic method of compaction in the finishing process and also to gain the strength of CSEB brick, stabilizer content was involved.

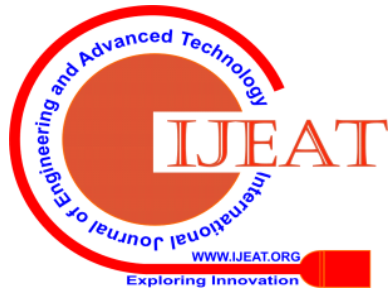


During production process normal clay brick requires more energy and also releases $\mathrm{CO}_{2}$ emission whereas CSEB brick was an alternate one which had a less energy consumption and low range releasing of $\mathrm{CO}_{2}$ emission. During manufacturing process, $\mathrm{CO}_{2}$ emission of different type of materials were given in table 1 .

Table- I: $\mathrm{CO}_{2}$ Emission of different materials

\begin{tabular}{|l|c|}
\hline \multicolumn{1}{|c|}{ Materials } & $\begin{array}{c}\text { CO } \\
\text { Kg/tonne }\end{array}$ \\
\hline CSEB & 22 \\
\hline Concrete Blocks & 143 \\
\hline Common Fired Clay Brick & 200 \\
\hline Aerated Concrete Blocks & 280 \\
\hline
\end{tabular}

Compared to manufacture of concrete masonry and fired clay brick unit, 10 percentage less consumption of energy was done by cement stabilized earth bricks. The dosage of glass fiber in the manufacturing of earth blocks was 50 grams per bag of cement, which also consumes very low energy for production. Due to the easiest manufacturing process of CSEB, it requires very less amount of skilled labours compared to concrete blocks and aerated blocks. And also the process of manufacturing has simplest stages of three stages such as preparation of soil, compression of mix and finally curing. The major parameter while selecting the soil for preparation of CSEB was perfect and careful selection of soil to absorb better strength. In the process of mix compression, proper compression load must be given to the mouldafter filling the mould by soil. Third stage of production was curing and in that curing process moist cured or curing by covered polythene sheet was better one. The gain of strength was disturbed if the CSEB was cured under natural humidity. And also it must be careful to remind, drying out while curing should be avoided to gain strength.

\section{MATERIALS AND PREPARATION}

\section{A. Materials}

The raw materials for the production of CSEB are earth soil, crushed sand, cement and lime. The soil is selected with the proportions as given in table 1 . The top soil is removed during mining, extraction made only if uniform soil layer available. The soil is tested for the required proportions, if not suitable fraction of the contents are added during mixing process to maintain the quality of production. The proportion for preparing CSEB is given in table 2. The average The color of the CSEB changes based on the source of the soil selected. The soil is allowed to dry naturally in the stockyard. Glass fibers of length $12 \mathrm{~mm}$ is used as additive in the mix. Cement and lime were added in the mix as stabilizers. The average liquid limit and plastic limit was maintained around $60 \%$ for soil, lime was prepared from oyster shell and slaked with portable water at site, fly ash based Portland pozzolana cement of 43 grade were used as stabilizers.

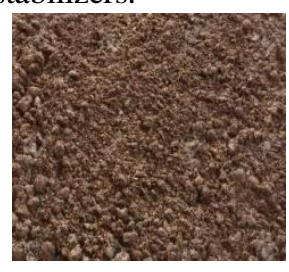

(a)

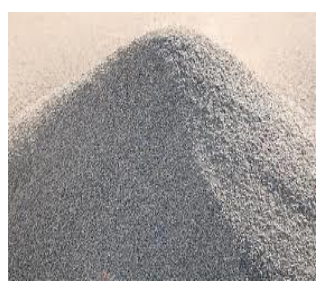

(b)

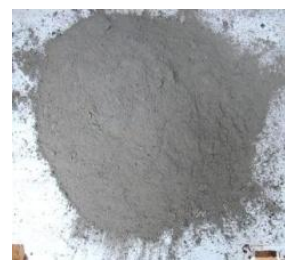

(c)

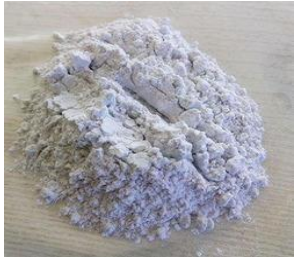

(d)

Fig. 1: (a) Earth Sand, (b) Crushed Sand, (c) Cement, (d) Lime

Table- II: Soil Proportion

\begin{tabular}{|l|c|}
\hline \multicolumn{1}{|c|}{ Ingredients } & Percentage \\
\hline Gravel & 15 \\
\hline Sand & 50 \\
\hline Silt & 15 \\
\hline Clay & 20 \\
\hline
\end{tabular}

Table- III: CSEB Proportion

\begin{tabular}{|l|c|}
\hline \multicolumn{1}{|c|}{ Ingredients } & Percentage \\
\hline Earth soil & 65 \\
\hline Crushed sand & 20 \\
\hline Cement & 10 \\
\hline Lime & 5 \\
\hline
\end{tabular}

\section{B. Mixing}

Soil mined from field contains stones of larger size, glass and other foreign materials. Before using, the soil is screened and pulverized in mechanical pulverizer. The soil is again screened in $5 \mathrm{~mm}$ screen before mixing. The proportion of stabilizers used was at average range [5][10] to maintain economy in production.Measurement of raw ingredients for proportioning is made by weight initially and converted to volume for easy handling. The ingredients are mixed dry in the mixing pan to get uniform consistency; water is then added and passed for moulding.

\section{Moulding and Compaction}

For preparing CSEB different mould sizes were used, the most commonly used mould size are $220 \times 100 \times 75$ $\mathrm{mm}$ and $152 \times 165 \times 324 \mathrm{~mm}$. The height of the mould will be usually more to hold more soil. The mix is spread onto the mould and surface leveled. The mix is initially compacted $20 \%$ by using table vibrator and then a pressure of $150 \mathrm{psi}$ is given to press the mix on the mould.

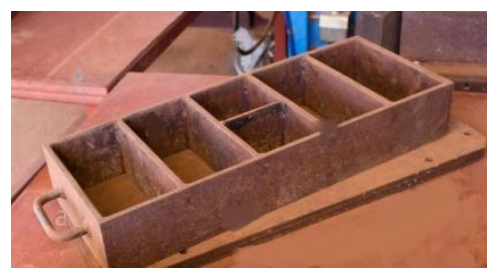

Fig. 2: Mould

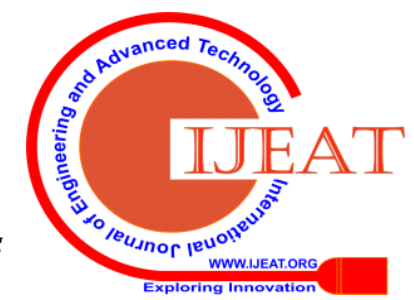




\section{Stacking and Curing}

The blocks were ejected from the mould and carefully stacked above concrete floor for curing. They are water cured for 28 days and then dispatched to site. They are visually inspected for uniformity in color, sharpness of the edges and surface hardness. it was observed the compressive strength increases with respect to time.
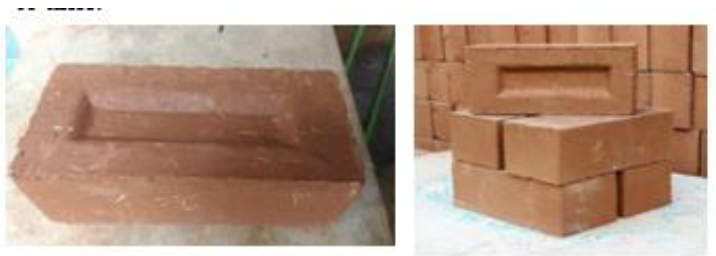

Fig.3: CSEB Bricks

\section{EXPERIMENT AND RESULT}

Two sample mixes were prepared. First mix CSEB is without glass fibers and second mix CSEBGF is with $1 \%$ glass fiber to the weight of cement. The samples were prepared and tested for its water absorption and compressive strength and dry density after 28days of curing. The results were tabulated in table 4. CSEB blocks were immersed in water for 24 hours and saturated weight is observed, then dried at oven and dry weight is obtained. Water absorption is measured as the ratio of difference between wet weight to the dry weight to the dry weight. The samples were preconditioned, load applied axially at a uniform rate of $14 \mathrm{~N} / \mathrm{mm}^{2}$ per minute till failure occurs as per [11] and maximum load at failure was noted. Blocks were tested in 100 tonne compression testing machine and the compressive strength isdetermined. The samples were tested for efflorescence as per [11] and found slight with an average of $10 \%$ surface efflorescence on both mixes.

\section{Table- IV: Water Absorption and Compressive Strength}

\begin{tabular}{|c|c|c|c|c|c|}
\hline Samples & $\begin{array}{l}\text { WA } \\
(\%)\end{array}$ & $\begin{array}{l}\text { Average } \\
\text { WA (\%) }\end{array}$ & $\begin{array}{c}\text { Compres } \\
\text { sive } \\
\text { strengt } \\
\text { h } \\
(\mathrm{MPa}) \\
\end{array}$ & $\begin{array}{c}\text { Average } \\
\text { Compre } \\
\text { ssive } \\
\text { strength } \\
\text { (MPa) }\end{array}$ & $\begin{array}{l}\text { Dry } \\
\text { density }( \\
\left.\mathrm{KN} / \mathrm{m}^{3}\right)\end{array}$ \\
\hline CSEB1 & 7.80 & \multirow{5}{*}{8.20} & 17.27 & \multirow{5}{*}{14.91} & 20.81 \\
\hline CSEB 2 & 8.60 & & 12.23 & & 20.53 \\
\hline CSEB3 & 7.95 & & 16.36 & & 20.79 \\
\hline CSEB4 & 8.72 & & 11.36 & & 20.47 \\
\hline CSEB5 & 7.90 & & 16.26 & & 20.77 \\
\hline CSEBGF1 & 8.10 & \multirow{5}{*}{7.94} & 14.63 & \multirow{5}{*}{16.11} & 20.68 \\
\hline CSEBGF2 & 7.75 & & 18.32 & & 20.86 \\
\hline CSEBGF3 & 7.93 & & 16.49 & & 20.79 \\
\hline CSEBGF4 & 8.12 & & 13.81 & & 20.66 \\
\hline CSEBGF5 & 7.80 & & 17.31 & & 20.81 \\
\hline
\end{tabular}

CSEB shows water absorption is within tolerable limit. The reduction in water absorption is due to denser packing of the raw materials, as the voids in the block is very less the water absorption is also very less. However it is observed that the CSEB retains water longer and takes more time to dry when compared to fired bricks, this is due to small voids in the blocks and water in voids takes long time to reach outer surface due to gravity. CSEBGF samples shows very little difference in water absorption. The compressive strength of CSEB is very high, which is about 3 times higher than fired clay bricks available in the local market. CSEBGF shows an average of $8 \%$ increase in compressive strength, which is almost equal to the concrete strength. The compressive strength of the blocks purely depends upon the type of earth soil used as raw material and the amount of stabilizer used. The density is also measures as higher than fired bricks. The surface texture of the block provides good bonding with the mortar. The cost of the CSEB and CSEBGF blocks are 25 percent cheaper than ordinary fired bricks as they do not require energy to burn. Compressed earth blocks with glass fibers showed a better performance in strength and water absorption. CSEB are manufactured from local available material which save the transport, fuel, time and money with little addition of stabilizers, they are bio degradable and does not harm the environment. Since burning of bricks is not done, it will save forest and resources. Requirement of lesser stabilizers makes it more economical, less energy consumption and eco friendly nature makes it a most promising sustainable material and hence recommended for ecofriendly green constructions

\section{ACKNOWLEDGEMENT}

The authors acknowledge Dhasor bricks, Kandanvilai, Kanyakumari District, TamilNadu for providing manufacturing support. 


\section{REFERENCES}

1. F.V.Riza, I.A.Rahman, and A.M.A.Zaidi, "A Brief Review of Compressed Stabilized Earth Brick (CSEB)," 2010 International Conference on Science and Social Research (CSSR 2010), December 5 - 7, 2010, Kuala Lumpur,Malaysia.

2. A.H.Abdullah, S.K.A.Bakar, I.A.Rahman J. C.Maxwell, "Indoor Thermal Performance of an Office Building using Conventional Brick Versus Interlocking Compressed Earth Brick (ICEB) Wall "International Journal of Construction Technology and Management Vol.1, No.1, 2013; ISSN 22894454.

3. Peter J Walker, "Strength and erosion characteristics of earth blocks and earth block masonary". J. Mater. Civ. Eng.2004.16:497-506.

4. J.C. Morela, A. Mesbah, M. Oggero, P. Walker," Building houses with local materials: means to drastically reduce the environmental impact of construction". Building and Environment 36 (2001)1119-1126.

5. A.H.Abdullah, S.Nagapan, A.Antonyova, K.Rasiah, $R$.Yunus, and S.Sohu,. "Strength and Absorption Rate of Compressed Stabilized Earth Bricks (CSEBs) Due to Different Mixture Ratios and Degree of Compaction". MATEC Web of Conferences 103, 01028(2017).

6. Esther Obonyo, "Optimizing the Physical, Mechanical and Hygrothermal Performance of Compressed Earth Bricks" Sustainability 2011, 3, 596-604; doi:10.3390/su3040596.

7. Marwan Mostafa, and Nasim Uddin," Effect of Banana Fibers on the Compressive and Flexural Strength of Compressed Earth Blocks" Buildings 2015, 5, 282-296; doi:10.3390/buildings5010282.

8. N.Zakham1,Y.ElRhaffari,A.Ammari,M.Cherraj1,H.Bouabid,K. Gueraoui, A. Samaouali, A. Mzerd,. "Influence of cement content on the thermal properties of compressed earth blocks (CEB) in the dry state" MATEC Web of Conferences 149, 01059 (2018).

9. N.A.Lakho, M.A.Zardari, A.A.Pathan, "Effect of Compaction on Compressive Strength of Unfired Clay Blocks ",Mehran University Research Journal of Engineering \& Technology, Volume 35, No. 4, October,2016.

10. Auroville Earth Institute (AVEI). Earth as a Raw Material. UNESCO Chair Earthen $\quad$ Architecture; 2009. Available:http://www.earthauroville.com/maintenance/uploaded_pics / 1-earth-raw-material-en.pdf.

11. BIS 3495 Part I,II,III: 1992, Methods of tests of burnt clay building bricks.

\section{AUTHORS PROFILE}

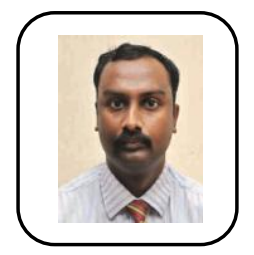

Mr. Bright Brabin Winsley.J is currently working as Assistant Professor, School of Civil Engineering at Mar Ephraem College of Engineering and Technology, Malankara Hills, Elavuvilai, Kanyakumari District. He completed his Bachelors degree in Civil Engineering from Anna University, Master degree in Construction Engineering and Management from CEG, Currently he is doing his research at Kalasalingam Academy of Research and Education, Krishnankovil. His areas of interest are eco friendly materials and design, vernacular construction techniques, passive cooling methods, green buildings and alternative construction materials. He is currently a member of ISTE

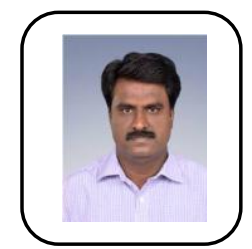

Dr.Muthukannan $\mathbf{M}$ completed his $\mathrm{Ph} . \mathrm{D}$ in Civil Engineering in Anna University, Chennai in the year 2010. He completed Master of Engineering in the field of Transportation Engineering and Management in College of Engineering, Guindy, Chennai in the year 2004. He completed his Bachelor of Engineering under Madurai Kamarajar University in the year 2000. He is presently working as a Professor in Civil Engineering department at Kalasalingam University, Tamilnadu, India. He is guiding for many Ph.D scholars in the field of transporation engineering and Geopolymer Technology. He has published various quality papers in the reputed journals. His main thrust research areas are Geopolymer technology, transportation network design, transport management and travel demand management.

Published By: 